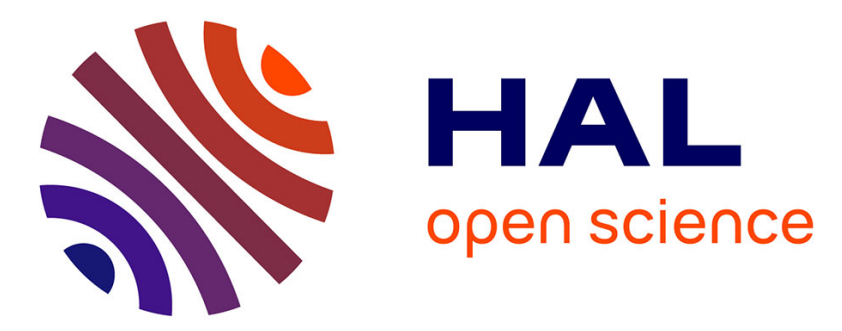

\title{
Modern Corporate Changes: Reinstating the Link between the Nature, Boundaries and Governance of the Firm
}

Cécile Cézanne

\section{- To cite this version:}

Cécile Cézanne. Modern Corporate Changes: Reinstating the Link between the Nature, Boundaries and Governance of the Firm. International Review of Applied Economics, 2008, 22 (4), pp.447-461. hal-00367732

\section{HAL Id: hal-00367732 \\ https://hal.science/hal-00367732}

Submitted on 12 Mar 2009

HAL is a multi-disciplinary open access archive for the deposit and dissemination of scientific research documents, whether they are published or not. The documents may come from teaching and research institutions in France or abroad, or from public or private research centers.
L'archive ouverte pluridisciplinaire HAL, est destinée au dépôt et à la diffusion de documents scientifiques de niveau recherche, publiés ou non, émanant des établissements d'enseignement et de recherche français ou étrangers, des laboratoires publics ou privés. 


\section{MODERN CORPORATE CHANGES: REINSTATING THE LINK BETWEEN THE NATURE, BOUNDARIES AND GOVERNANCE OF THE FIRM}

Cécile CÉZANNE-SINTÈS

University of Nice - Sophia Antipolis

GREDEG UMR $6227 / C N R S$

250 rue Albert Einstein, 06560 Valbonne, France

Phone: (33-4) 939543 52; Fax: (33-4) 93653798

Email: cecile.cezanne@gredeg.cnrs.fr

30 October 2007 


\title{
MODERN CORPORATE CHANGES: REINSTATING THE LINK BETWEEN THE NATURE, BOUNDARIES AND GOVERNANCE OF THE FIRM
}

\begin{abstract}
The theory of the firm and corporate governance are two fields of analysis traditionally tackled separately in the economic literature. This paper seeks to rediscover the link between the nature, boundaries and governance of the firm on the basis of changes in corporate industrial firms. We advance the argument that, to understand the human capital-intensive firm, this analytical interconnection should be restored. On the basis of Critical Resource Theory, we present an innovative vision of the nature, boundaries and governance of firms whose productive activity is built around its key partners' human capital. The organisational mode of governance has changed linked to a renewed conception of the firm. What we term the 'multi-resources' model of governance of the firm depends on an original representation of the structure, organisation and power relationships of modern firms, whose value arises from the accumulation of specific human capital. Consequently, the multi-resources model involves hybrid governance instrument in order to protect the integrity of the human capitalintensive firm.
\end{abstract}

JEL Classification: J 24, J 41, L 22, L 23

Key words: human capital, nature and boundaries of the firm, corporate governance, Critical Resources Theory. 


\section{Introduction}

Publication in 1937 of the 'Nature of the Firm' by Coase and The Modern Corporation and Private Property by Berle \& Means in 1932, gave rise to two distinct fields of analysis. On the one hand, Coase's article gave birth to an abundant literature on the nature and the boundaries of the firm. Debates on the emergence of the firm in a market economy, and the possibility to distinguish it from cooperation and price coordination stem from this reference work (Williamson, 1975, 1985; Klein et al., 1978). On the other hand, Berle \& Means's book was the beginning of questions about corporate governance. The Modern Business Corporation is characterised by a separation between ownership and control, a separation that generates conflicts of interest between shareholders and managers, which are solved by contractual mechanisms (Jensen \& Meckling, 1976; Fama, 1980; Fama \& Jensen, 1983). ${ }^{1}$

Since the mid 1980s, an increasingly large portion of the value of firms has become attributable to intangible assets - including specialised human capital (competencies, knowledge, experience, etc. of employees) - that cannot be appropriated (Teece, 2000; Hall, 2001, Brynjolfsson et al., 2002). Basically, both recent financial and technological developments, and industrial restructuring, have induced major changes in the nature, the hierarchical structure, the work organisation and also in the internal regulation of firms. These changes cannot be explained either only by the Modern Theory of the Firm or only by corporate governance analysis.

The purpose of this paper is to explore attempts to reconcile these two fields of analysis that traditionally have been separate, by considering the transition from the physical to the human capital-intensive firm. This paper restores the link between the nature, boundaries and governance of the firm, which is not very well documented in the literature 
(Bolton \& Scharfstein, 1998). It is not possible to completely answer the Coasian question relating to the existence and the boundaries of the firm without understanding the corporate governance issues raised by Berle \& Means in their book. Reciprocally, it is not possible to have a complete understanding of the general system by which firms are owned and managed, discussed by Berle \& Means, without having some notion of what a firm is, i.e. neglecting Coase's perspective.

This paper considers corporate governance as a system of power relationships between the different corporate members that own the resources fundamental to the productive entity. This general definition of corporate governance refers to a vision of the firm as a combination of specific and critical resources (Penrose, 1959; Aoki, 1984; Prahalad \& Hamel, 1990; Barney, 1991; Rajan \& Zingales, 1998) and, thus raises the age-old question of what a firm is (Zingales, 1998). In other words, we suggest that it is impossible to study the governance of an organisation whose nature and boundaries are not defined. And, the way a firm is governed changes with the way its nature and its boundaries are characterised.

The link between the two fields of analysis needs to be restored in order to understand the modern human capital-intensive firm, for instance, a large proportion of the new service companies. $^{2}$ This is justified by the increased importance of human assets in economic activity. Business services activities are a significant and growing part of modern economies. The services sector now accounts for over $70 \%$ of total employment and value added in the OECD economies (OECD, 2005). This indicates that firms built around employees' resources produce $70 \%$ of the added-value in the sector. These data suggest that it is human capital rather than physical capital that boosts economic growth. 
The paper is organised as follows. Section 2 highlights the merits of the link between how to define the firm and corporate governance. In this perspective, we emphasise the seminal developments of Transaction Cost Economics (TCE) and the importance of focusing on the organisational history of industrial firms. Section 3 shows that some more recent essays that have tried to analyse the transition of firms to entities based on their human assets (Critical Resource Theory - CRT), extend the definition of the boundaries and coordinating role of the firm. Because of the immaterial and non-transferable nature of human capital, the way one deals with corporate governance issues has to be reconsidered by overtaking the restrictive duality between shareholder value versus stakeholder value. Thus, we propose an original investigation of the principles and mechanisms of governance of the human capitalintensive firm. The acquisition, the allocation and the exercise of power, on the one hand, and hold-up problems related to human capital, on the other, are at the core of what we term the 'multi-resources' governance of the firm. Section 4 concludes.

\section{The link between the Modern Theory of the Firm and corporate governance: Theoretical and historical evidence}

Power and coordination are at the core of the articulation of corporate governance in the theory of the firm (2.1.). This articulation is all the more evident if one explores the latest changes concerning the nature and the boundaries of the firm linked to the growing importance of human capital (2.2.).

\subsection{Coordination and power in the theory of the firm}

Nowadays, economic analysis seems to conceal the complementary vision between the theory of the firm and corporate governance. It is a link that is missing, insofar as this link has 
existed since the origins of the Modern Theory of the Firm. Indeed, the premises of the relationship between the two fields of analysis date back to the seminal work of Coase (1937) and the foundation of TCE.

\section{TCE: The origins of the analytical link.}

Transaction Cost Theory (TCT) bases the existence of the firm on informational market imperfections. The price system fails to effectively coordinate economic activities: it induces the costs of discovering prices, but also introduces negotiation costs and the costs of controlling contracts. In this context, hierarchical organisations would be able to minimise these transaction costs due to productive activities: within the firm, the allocation of resources by authority, represented by the entrepreneur-coordinator, is a more efficient mechanism even if it creates some organisation costs. Within the same framework, the notions of 'transaction costs' and 'authority' and their conceptual combination establish the dichotomic vision between 'make' and 'buy'.

In TCT, transaction costs are linked to asset specificity, and since contracts are incomplete, economic agents, who are opportunist by nature, are incited to make use of the weaknesses of contracts without necessarily taking into account the interests of the firm. In other words, contractual incompleteness generates hold-up risks. This inimical behaviour discourages the party subject to possible expropriation from making specific investments critical to the contractual relationship, and can cause inefficiencies during renegotiation (Klein et al., 1978). On the basis of these developments, TCT proposes a preliminary approach of power relationships between corporate members. Within hierarchies, the authority of the employer over the employees is the central mechanism of coordination (Williamson, 1975). The firm is the governance structure ${ }^{3}$ able to prevent hold-up risks. More 
precisely, Zingales (1998, p.500), in the spirit of Williamson (1985), defines 'a governance system as the complex set of constraints that shape the ex-post bargaining over the quasi-rents generated in the course of a relationship'.

Although TCT represents a robust approach to the boundaries of the firm, some confusion remains as far as the definition of the firm is concerned: the concepts of hierarchy (even through vertical integration) $^{4}$ and authority are put on the same level (Baudry \& Gindis, 2004)

Nevertheless, this approach can be considered to be a more relevant foundation for the link between the nature, the boundaries and the governance of the firm. Some authors continue to support Agency Theory as the unique theory of the firm providing a foundation for dealing with corporate governance objectives and practices. However, by defining the firm as a combination of explicit inter-individual contracts, Agency Theory does not clearly distinguish between hierarchical transactions and market transactions (Eisenberg, 1999). Although it provides some interesting prescriptions as far as incentives and control mechanisms are concerned, Agency Theory is not a theory of the firm theory, i.e. it fails to provide any insights into the boundaries of the firm.

In considering transaction costs and authority in the frame of microeconomics applied to industrial organisation, the economic literature has investigated corporate governance issues on the basis of hold-up problems, while dealing with the institutional division of labour. Incomplete Contracts Theory (ICT) is proposed as a revised and formalised conception of the transactional approach. ICT develops a vision of the firm based on its physical assets, whose ownership raises the problem of the management of hold-up threats. 


\section{ICT: Hold-up and asset ownership.}

In line with the developments of TCT, ICT explains that transactions costs are due to hold-up risks induced by under-investment. It focuses on efficiency considerations and incentive structures to deal with hold-up problems. ICT considers ownership as the unique way to address potential hold-ups and incentive alignments in a world of incomplete contracting and divergent interests (Holmstrom \& Roberts, 1998); ownership is the solution to regulating power relationships between agents that participate in productive transactions (Grossman \& Hart, 1986; Hart \& Moore, 1990).

In other words, ICT views the firm as a collection of physical assets that are commonly owned, whose main governance objective is to satisfy the owners' interests. The boundaries of the firm are clearly defined by the legal perimeter of the productive entity; physical assets ownership delimits the boundaries of the firm. Hold-up problems can be solved on the basis of an optimal allocation of residual rights of control: residual rights of control must be granted to a unique agent, i.e. to a unique authority. Governance structures allow the owner to take decisions not specified in the initial contract (Hart, 1995). In this context, efficiency, legal ownership and asset specificity are at the core of corporate governance considerations and the objective is to save on transactions costs and to maximise the value for the owner.

Moreover, ICT overlooks the importance of human capital; human capital is always subordinated to the development of firm-specific fixed capital (Hart, 1989; Klein, 1991). Yet, within ICT, some authors have tried to overcome the restrictive conception of the firm as a unified structure of property rights (Milgrom \& Roberts, 1992). Combining the theory of 
incentives and TCT, they take account of the importance of resource complementarities.

Milgrom \& Roberts (1995, p. 181) state that complementarity means 'doing more of one thing [and] increases the return from doing more of another'.

Complementarities between productive resources are at the core of the firm.

Consequently, hold-up threats can originate in the human capital of each productive corporate

partner. ${ }^{5}$ Power relationships and corporate governance mechanisms have to be reconsidered on the basis of this central dimension. In fact, human capital is one of the main factors in the changing nature, boundaries and governance of corporate industrial firms.

\subsection{Changes in the structure, organisation, and internal regulation of industrial corporate} firms: Historical evidence

Since the middle of the twentieth century, the structure and the organisation of the firm, and the way that relationships between different partners are managed, have changed.

Created to exploit scale and scope economies, the Modern Business Corporation, which is physical capital intensive and vertically integrated, dominated until the $1980 \mathrm{~s}$. The boundaries of big corporation are clearly defined by the legal ownership of the physical assets, and the main corporate governance issue is to control managers' behaviour to protect external investors (Shleifer \& Vishny, 1997). The emergence of the human capital-intensive firm in the 1990s, and its growing role in the economic system, have tended to question the managerial configuration of the Modern Business Corporation and its corresponding shareholding mode of corporate governance. In other words, the transition from the Modern Business Corporation to the human capital-intensive firm marks a break in the way that the boundaries and firm governance can be understood. The missing link between the two fields 
of analysis cannot be discussed only on the basis of the 'managerial revolution' in the large, hierarchical, multidivisional business corporation (Chandler, 1977).

Recent industrial reorganisations based on large movements in terms of vertical disintegration (Langlois, 2003; Leiblein \& Miller, 2003; Jacobides, 2005), and also technological innovations ${ }^{6}$ and globalisation of finance, imply that productive activity does not require only traditional production factors such as fixed capital. Productive activity also requires competences, human capital, organisational structures and procedures, and all the other resources described as intangible assets (Brynjolfsson et al., 2002, p.137).

Employees are crucial resources for innovative firms (Ha1l, 2000; Lund Vinding, 2006). In this dynamic context, workers enhance their value as differentiated human assets that use physical tools optimally (Zingales, 2000). Human capital has become more important than physical capital for productive activities. Indeed, on the basis of know how, knowledge, behaviour and the attributes that affect individual capabilities, i.e. adaptability, initiative, motivation, etc., employees represent specialised human capital that is essential for the firm to exploit growth opportunities. This human capital represents a critical resource for the production processes of firms (Kochan \& Rubinstein, 2000). The level of knowledge, skills and capabilities attained by employees is an important source of economic value for the firm (Becker, 1976). According to Blair (1995, p.292) ‘A knowledge company’s primary resource and principal competitive advantage is the knowledge that its employees possess'.

Moreover, for Charreaux \& Desbrières (2001), a firm creates value because it owns key competences difficult to imitate, e.g. skills linked to human or organisational capital rather than financial capital. Thus, faced with industrial mutations, firms will choose to globally manage the competencies of their employees. 
In this context, the stakeholder model, ${ }^{7}$ which recognises the strategic nature of human capital as far as rent creation is concerned (Coff, 1999), has been developed. Unlike the shareholder model, which focuses on satisfying investors' interests by monitoring managers' behaviour, the stakeholder model aims to avoid conflicts by disciplining stakeholders ${ }^{8}$ and particularly managers. In other words, the stakeholder model is framed by multiple principalagent relationships (Hill \& Jones, 1992; Laffont \& Martimort, 1997). Thus, (like the shareholder model) it is based on a vision of the firm as a 'nexus of contracts', which operates like the market system. ${ }^{9}$

Nevertheless, because human capital cannot be legally appropriated, the approach of the firm has to be re-founded (Blair, 1999; Araujo et al., 2003). Similarly, the power invested in human capital must take account of the intangible and inalienable nature of this critical asset. As the importance of human capital has increased, power is no longer concentrated only within top management, although this latter may have the residual rights of control. Power, instead, is dispersed among all stakeholders, who are valuable resources. The boundaries of the human capital-intensive firm are not clearly delimited by its legal perimeter. The boundaries of the human capital-intensive firm have to be defined in an extended way, in functional terms, and the governance of the firm has to be revised.

\section{The boundaries and the governance of the human capital-intensive firm}

Human capital needs to be introduced as a key dimension in firm analysis. Its role and its effects must be discussed in line with the dominant contractual framework, that is, ICT (3.1.). In this perspective, CRT develops conceptual innovations to set up an original approach to the 
human capital-intensive firm while suggesting an adapted re-examination of the corresponding modes of the exercise of authority and power (3.2.).

\subsection{Human capital and hold-up: Extending ICT}

In ICT, power based on specific human assets does not change the incentive coordination problem; ICT initially overshadows the assumption of hold-up problems due to firm-specific human capital owned by individual members.

However, property rights (on physical assets) are not sufficient to guarantee incentive complementarity (Holmström \& Roberts, 1998; Holmström, 1999). Human capital takes on intrinsic importance, beyond its combination with physical capital advanced by ICT. For this reason, the vision of the firm as a 'legal fiction' cannot efficiently coordinate investments.

Human capital can be appropriated neither by the firm nor by any of the firm's partners. Indeed, an agent cannot transfer its residual rights of control on its human capital to others through an incomplete contract, for an extended period (Grossman \& Hart, 1986; Hart $\&$ Moore, 1990). Human capital is inalienable such that contracts for its management do not give the same residual rights of control as contracts relating to physical capital (Gibbons, 2005). Consequently, the authority relationship between employer and employee, as described by Coase (1937) and Simon (1951, p.294), needs to be reviewed. Basically, 'In the employment relationship, whoever possesses legal control over the firm's assets has the authority' (Morroni, 2006, p.208).

But, whoever possesses legal control over the firm's assets cannot fully control human capital - because of its non-appropriable nature - even if employment contracts spell out the 
legal rights as 'the right of employees to quit' (Baron \& Kreps, 1999, p.66). The employment relationship is affected in favour of the specialised employee whose specific human capital strengthens his or her negotiating power. Thus, corporate governance issues, i.e. power relationships and underlying control and incentive systems, cannot be solved solely on the basis of ownership. Therefore, firms built around the partners' human capital cannot be satisfactorily defined in terms of the legal structure of property rights. The focus on the theory of the firm must shift to studying the economic and functional nature of organisations (Rajan \& Zingales, 2001; Baudry \& Gindis, 2004). The vision of the firm as a combination of physical assets, commonly owned, must be abandoned for an improved conception of the firm based on the specialisation of assets decisive to the productive activity of the firm, notably human assets. Taking account of all these considerations, CRT proposes an original vision of the nature and the boundaries of the firm, and suggests an original governance of the human capital-intensive organisation.

\subsection{CRT: Access, complementarity and specialisation of human assets}

CRT initially develops a conception of the firm as a 'nexus of specific investments' (Zingales, 2000, p. 1648) in human assets. On the basis of this renewed vision of the firm, we show that corporate governance practices necessarily change towards what we term the "multiresources' governance of the firm. In other words, the coordination of human assets and of their complementarities is at the core of the analysis of the human capital-intensive firm and establishes a re-consideration of the principles and mechanisms of the governance of the firm.

\section{The firm as a nexus of specific human capital investments.}

On the basis of CRT, we conceptualise the division of tasks and power relationships within a human capital-intensive firm. A firm builds its productive activity on the critical resource 
owned by any corporate member. ${ }^{10}$ This resource is decisive for the firm insofar as it enhances the development of its production process.

On the one hand, the firm can influence its partners' behaviour by regulating access to the critical resource. By providing some competent partners ${ }^{11}$ and some productive units with the right to use or to work with the critical resource (Rajan \& Zingales, 1998), partners adjust their investments according to the interests of the firm in order not to jeopardise the joint value. The more partners invest in human capital, the more significant will be the rents to be shared within the coalition. They know that their rewards will be greater if they control the critical resource of the firm. Mutual dependence promotes the accumulation of specific human capital investments.

On the other hand, by themselves specialising, partners become key elements of the productive activity of the firm on the basis of the complementarities built between the firm's critical resource and the employees' human capital. Mutual dependencies are a source of power because specific human assets cannot be redeployed outside the firm without a cost.

In the critical resource framework, power comes from access to human capital that is critical for the firm's production process. The rights of control on human capital are inalienable (Gibbons, 2005); therefore, control over human capital does not refer to ownership. Control over human capital depends rather on the regulation of access rights to a critical resource. A corporate member that is granted access does not acquire an additional residual right of decision; he or she can enhance their value by specialising in line with the firm's process and its critical resource (Blair \& Stout, 1999; Rajan \& Zingales, 2001). 
Access is a means by which each party can improve its economic power. On the one hand, through regulated access over time the firm improves its market valorisation and its growth opportunities. As it is a nexus of specific and complementary investments in human capital constituted of the productive team (Teece et al., 1997), the firm cannot be imitated instantaneously by real and/or potential competitors. Moreover, the more agents specialise, the more power is maintained and increased so that at some point, the firm becomes the nexus of the specific investments itself, i.e., the firm becomes the critical resource. According to Zingales (2000, p.1645) 'what distinguishes the firm from the market is the web of specific investments built around a critical resource'. By giving up a part of its control to partners who are granted access to the critical resource, the firm loses some negotiation power. Therefore, on the other hand, valuable partners, who are granted access, control the nexus of critical resources so that they can multiply their outside opportunities. This power depends on the ability of partners to make firm-specific human capital investments. Partners control their own human capital and trade off specialisation to the firm against the exercise of outside options. The employees have the residual right to leave the firm. The simple threat to deprive the firm of specific human capital provides them with improved bargaining power. As they do not have alienable rights of control on the critical resource of the firm, partners do not have legal power in the firm. But, they do have a factual power on the basis of the control they are endowed with by using or working with, i.e. controlling, the critical resource of the firm.

In other words, power relationships are reflected in the structural organisation and internal division of labour. The firm does not require other partners to develop their human capital excessively, because it wants its organisational rents to be protected. Thus, the firm defines and manages team work through synergies created by regulating access. In a symmetric way, partners search to enrich their tasks and to make firm-specific investments. 
By specialising and accumulating knowledge and competencies, these individuals make themselves indispensable to the firm and enhance their outside value. The regulation of access is a privileged method to promote specific investments in human capital. The regulation of access to the critical resource, as a non-contractual ${ }^{12}$ agreement, is a superior mode of coordination to ownership in the particular case of the human capital-intensive firm.

To summarise, therefore, whereas ownership legally associates physical assets to a firm, complementarities join human assets within a production team (Milgrom \& Roberts, 1992). The human capital-intensive firm can be viewed as a team organisation that coordinates productive co-specialisation. In other words, via the regulation of access, cospecialisation and synergies arise from a team production in which each partner is decisive based on his or her specific human capital investments.

In line with the Coasian approach to the firm, in a human capital-intensive firm coordination of productive activities is based on authority and power. However, the boundaries of the human capital-intensive firm are not precisely and definitively outlined. The boundaries of the human capital-intensive firm extend to all partners specialised in the productive entity, inside and outside its legal perimeter. Indeed, as this kind of firm is built on non-appropriable resources, its boundaries cannot be delimited on the basis of the structure of property rights. They should rather be defined as economic or functional boundaries on the basis of the power the firm gets by regulating access; the firm coordinates partners taking part in the productive activity inside and outside its legal boundaries. In this perspective, the institutional division of the coordination labour between the human capital-intensive firm and the market relationships system, is based on the absence of a (re)allocation of property rights within this kind of hierarchical organisation. In fact, employees are not granted legal rights of 
control. Yet, such an allocation of property rights would promote the internal transfer of funds and resources to the most profitable productive divisions (Brusco \& Panunzi, 2005).

However, these productive divisions could change their investment behaviour to opportunistically protect their own interests.

This analysis of the boundaries of the human capital-intensive firm combined with its particular mode of acquisition, of allocation and of exercise of power, suggests that a renewed vision of the governance of the firm should be developed (Porter-Liebeskind, 2000; Rajan \& Zingales, 2000; Roberts \& Van den Steen, 2000; Keenan \& Aggestam, 2001). We thus propose a composite model of governance whose main objective is to maximise the 'multiresource' value of the firm.

\section{Objectives and operational modes of coordination of human capital: The multi-resources} value.

As the distinctive value of the human capital-intensive firm depends on resources that cannot be easily appropriated, its boundaries are often altered by the power of influential partners. Specialised partners have negotiating power by virtue of the mutual dependencies they have created. They can expropriate a large fraction of the value of the firm by developing outside opportunities. ${ }^{13}$ The risk of hold-up is high and the organisational form of the firm can be changed. In this context, the human capital-intensive firm has to develop a system of governance able to guarantee a satisfying alignment between the capacity to capture growth opportunities and the allocation of rents (Rajan \& Zingales, 2000; Zingales, 2000). Because the possibility of renegotiation jeopardises long-term commitments, growth prospects are crucial in making the promise of future rents credible. As power and rents are not concentrated, but diffused among multiple key partners, even outside the legal boundaries of 
the firm (as for subcontractors essential to the firm), the main objective of the governance of the human capital-intensive firm is to protect the integrity of the firm.

The organisational mode of governance has to change. Focusing on the firm built around its human assets, investigations have to study mechanisms that give to the hierarchical organisation of the firm the power to motivate, to control, and above all to retain specific human capital in order to maximise its value. Partners have to be provided with incentives to continue their relationship with the firm so that the firm can retain the wealth indispensable to its productive activity. Corporate governance does not deal only with efficient modes of resolving conflicts in order to maximise shareholder or stakeholder value. The governance of the firm consists of encouraging key partners not to quit the firm and to make firm-specific human capital investments. The governance of the human capital-intensive firm that we describe in this paper as the 'multi-resources model' recognises specialised partners as complementary valuable resources that enhance the value of the firm and ensure its durability. The final objective of the multi-resources model is to maximise the value of the various critical intangible assets owned by key employees and other partners in the nexus of specific investments, i.e. to maximise the multi-resources value.

The multi-resources model is based on a set of instruments of coordination. ${ }^{14}$ The governance of the human capital-intensive firm can be described as a composite model built on an association of standard mechanisms (used in the shareholder model or/and in the stakeholder model) and innovative practices that take into account the inalienable and nontransferable nature of human capital. These practices can affect either extrinsic or intrinsic motivation (Deci, 1975; Kreps, 1997; Osterloh \& Frey, 2000; Bénabou \& Tirole, 2003). ${ }^{15}$ Intangible critical resources can be incited, co-specialised and retained on the basis of a 
combination of different coordinating and regulatory mechanisms whose use proportion depends (notably) on the hierarchical structure and the functional boundaries of the firm. Table 1 summarises the major attributes of the multi-resources view compared to the shareholder and the stakeholder approaches.

$<$ Table 1 here $>$

Firstly, beyond their traditional role of financing, outside equities can lock in relationships among stakeholders (Myers, 2000). By ensuring an attractive distribution of outside equities, the firm can protect its long-term viability. The solution is to associate key partners (mainly employees here) with the financial capital structure of the firm and, thus, to provide them with power (Frye, 2004). The idea is to preserve the firm as a nexus of specific investments, by promoting the alignment of partners' interests. This modality of governance within the human capital-intensive firm would reduce potential sources of conflicts.

Secondly, as job rotation and temporary specialised labour markets have increased, corporate members tend to be more volatile. They improve their negotiating power. Appropriate incentives, for example, profit-sharing, have to be developed to encourage partners' efforts at good corporate performance and to ensure their loyalty. Therefore, the generalised awarding of stock options to employees continues to be an important regulation means to compensate and to retain employees (Ittner et al., 2003; Oyer \& Schaefer, 2005). While the rights of control associated with ownership may have diminished, the role of ownership in coordinating partners may have increased. Moreover, participative management and organisational design can interact with ownership in order to minimise hold-up problems in human capital 
Thirdly, within the firm, the collective participation of employees in decision processes is an important motivating method insofar as it partly affects the subordination relationships among employer and employees (Goodijk, 2000). Better board and committee representation of employees is part of this corporate governance method (Luoma \& Goodstein, 1997; Hillman et al., 2001). Information rights, consultation rights, and comanagement rights strengthen employees' power.

Fourthly, team production supports the multi-resources mode of governance. By working together, specialised employees interact and strengthen the complementarity of their own critical human capital. The more employees increase the value of their firm-specific human capital, the more it is costly to redeploy this human capital outside the firm and employees continue to be retained by the firm.

Fifthly, an increased vertical and horizontal communication among employees through hierarchical intermediaries is a solution to optimally coordinating employees within the organisation. In other words, hierarchy can yield power to employees that occupy middle positions in the hierarchy by providing them with control over some resources. ${ }^{16}$ Being given a higher position in the hierarchy is synonymous with the higher rents that employees can appropriate. Thus, these employees strengthen their relationships with the firm (Rajan \& Zingales, 2001).

Lastly, setting up a system of job rotation could reduce hold-up problems for the human capital-intensive firm (Halonen-Akatwijuka, 2004). Basically, specialised employees with task-specific human capital are indispensable because nobody else can perform their jobs. 
Hold-up threat is great and should be limited. Rotation removes the hold-up power originating in human capital because other employees are able to perform the same job.

\section{Conclusion}

The objective of this paper was to reinstate the link between two fields of analysis traditionally investigated separately - the boundaries of the firm, and governance of the firm on the basis of an extensive analysis of the human capital-intensive firm. The outcomes obtained are as follow.

Firstly, the link between the two fields of analysis appears with the emergence of the Modern Theory of the Firm, i.e. with the seminal work of Coase (1937).

Secondly, the contractual framework develops a restrictive conception of the firm as a unified structure of property rights over physical assets. However, since the mid 1980s, the structure and the organisation of the firm, and also the power relationships between the firm and its internal and external partners have changed. The growing importance of human capital in the productive activity of firms is at the core of these mutations. Nevertheless, the central dimension of human capital is frequently neglected by economists writing about the firm.

Thirdly, CRT is the first approach to the firm that recognises human capital as the asset decisive to its competitiveness. It establishes an original analysis of the human capitalintensive firm founded on team production, and suggests new foundations for corporate governance. 
Fourthly, what we term the multi-resources view in this paper is based on original mechanisms of acquisition, allocation and exercise of power in a firm defined as a nexus of specific human capital investments. Because of the immaterial and non-transferable nature of knowledge, talents and competencies, the boundaries of the human capital-intensive firm are economically defined on the basis of regulation of access to the activities coordinated by the firm. Therefore, the multi-resources model of governance of the firm aims to incentivise internal and external partners that work in teams to co-specialise within the firm and not to leave it.

Lastly, a model of creation and repartition (or appropriation) of the multi-resources value is developed on the basis of the operational instruments of coordination. The multiresources model reduces efficiency losses due to underinvestment resulting from human assets specificity and underlying hold-up risks.

These outcomes do not exhaust the research agenda related to the link between the nature, boundaries and governance of the firm, referred to in this paper on the basis of the emergence of the human-capital intensive firm. In order to go deeply into the multi-resources model, we need an empirical evaluation of human capital-intensive firm behaviour in terms of work organisation and incentives and control methods. Correlations between the multiresources model and firm performance are needed. Theoretically, CRT is a first step towards a renewed Modern Theory of the Firm in developing an original vision of the firm while suggesting a corresponding model of firm governance. Future research should extend this approach by studying in depth some theoretical concepts, including human assets specificity compared to physical assets specificity, and the associated underlying coordination problems. 
Future research should develop a general (not a particular) theory of the firm associated to a theory of corporate governance applicable to all types of firms.

\section{References}

Aoki, M. (1984) The Co-operative Game Theory of the Firm (Oxford, Oxford University Press - Clarendon Press)

Araujo, L., Dubois, A. \& Gadde, L-E (2003) The Multiple Boundaries of the Firm, Journal of Management Studies, 40, pp.1255-1277.

Barney, J. B. (1991) Firm Resources and Sustained Competitive Advantage, Journal of Management, 17, pp.99-120.

Baron, J. N. \& Kreps, D. M. (1999) Strategic Human Resources: Frameworks for General Managers (New York, Wiley \& Sons).

Baudry, B. \& Gindis, D. (2004) Specificity of the network-firm and the boundaries of the firm, in: I. D. Salavrakos (Ed.), Aspects of globalisation, regionalisation and business, Part 5, Ch. 21, pp.273-288 (London: ATINER).

Becker, G. S. (1976) The Economic Approach to Human Behavior (Chicago, University of Chicago Press).

Bénabou, R. J. M. \& Tirole, J. (2003) Intrinsic and Extrinsic Motivation, Review of Economic Studies, 70, pp.489-520.

Berle, A. A. \& Means, G. C. (1932) The Modern Corporation and Private Property (New York: Harcourt, Brace and World).

Bhide, A. V. (2000) The Origin and the Evolution of New Businesses (New York, Oxford University Press)

Blair, M. M. (1995) Ownership and Control: Rethinking Corporate Governance for the Twenty-First Century, (Washington, Brookings Institution Press). 
Blair, M. M. (1999) Firm-Specific Human Capital and Theories of the Firm, in: M. M. Blair \& M. J. Roe (Ed.), Employees and Corporate Governance, Ch. 2, pp.58-90 (Washington, Brookings Institution Press).

Blair, M. M. \& Stout, L. A. (1999) A Team Production Theory of Corporate Law, Virginia Law Review, 85, pp.248-328.

Bolton, P. \& Scharfstein, D. S. (1998) Corporate Finance, The Theory of the Firm, and Organizations, Journal of Economic Perspectives, 12, pp.95-114.

Brusco, S. \& Panunzi, F. (2005) Reallocation of Corporate Resources and Managerial Incentives in Internal Capital Markets, European Economic Review, 49, pp.659-681.

Brynjolfsson, E., Hitt, L. M. \& Yang, S. (2002) Intangible Assets: Computers and Organizational Capital, Brookings Papers on Economic Activity, 1, pp.137-198.

Chandler, A. D. Jr (1977), The Visible Hand: The Managerial Revolution in American Business (Cambridge: The Belknap Press of Harvard University Press).

Charreaux, G. \& Desbrières, P. (2001) Corporate Governance: Stakeholder Value Versus Shareholder Value, FARGO Working Papers Series, 1010301.

Coase, R. H. (1937) The Nature of the Firm, Economica, 4, pp.386-405.

Coff, R. W. (1999) When Competitive Advantage Doesn't Lead to Performance: The Resource-Based View and Stakeholder Bargaining Power, Organization Science, 10, pp.119-133.

Deci, E. L. (1975) Intrinsic Motivation (New York, Plenum Press).

Donaldson, T. \& Preston, L. E. (1995) The Stakeholder Theory of the Corporation: Concepts, Evidence and Implications, Academy of Management Review, 20, pp.65-91.

Eisenberg, M. A. (1999) The Conception That the Corporation is a Nexus of Contracts, and the Dual Nature of the Firm, Journal of Corporation Law, 24, pp.819-836. 
Fama, E. F. (1980) Agency Problems and the Theory of the Firm, Journal of Political Economy, 88, pp.288-307.

Fama, E. F. \& Jensen, M. C. (1983) Separation of Ownership and Control, Journal of Law and Economics, 26, pp.301-326.

Freeman, R. E. (1984) Strategic Management: A Stakeholder Approach (Boston, Pitman Press).

Frye, M. (2004), Equity-Based Compensation for Employees: Firm Performance and Determinants, Journal of Financial Research, 27, pp.31-54.

Gagné, M. \& Deci, E.L. (2005), Self-Determination Theory and Work Motivation, Journal of Organizational Behavior, 26, pp.331-362.

Gibbons, R. (2005) Four formal(izable) theories of the firm?, Journal of Economic Behavior and Organization, 58, pp.200-245.

Goodijk, R. (2000), Corporate Governance and Workers' Participation, Corporate Governance: An International Review, 8, pp.303-310.

Greenwood, J. \& Jovanovic, B. (1999) The Information-Technology Revolution and the Stock Market, American Economic Review, 89, pp.116-122.

Grossman, S. J. \& Hart, O. D. (1986) The Costs and Benefits of Ownership: A Theory of Vertical and Lateral Integration, Journal of Political Economy, 94, pp.691-719.

Hall, R. E. (2000) E-Capital: The Link between the Stock Market and the Labor Market in the 1990s, Brookings Papers on Economic Activity, 2, pp.73-102.

Hall, R. E. (2001) Struggling to Understand the Stock Market, American Economic Review, Papers and Proceedings, 91, pp.1-11.

Halonen-Akatwijuka, M. (2004) Organizational Design, Technology and the Boundaries of the Firm, Discussion Paper Series, nº 02/540, University of Bristol, Department of Economics. 
Hart, O. D. (1989), An Economist's Perspective on the theory of the firm, in: P. J Buckley \& J. Michie (Ed.), Firms, organization and Contracts: A reader in Industrial Organization (New-York, Oxford University Press).

Hart, O. D. (1995) Firms, Contracts, and Financial Structures (Oxford, Oxford University Press)

Hart, O. D. \& Moore, J. (1990) Property Rights and the Nature of the Firm, Journal of Political Economy, 98, pp.1119-1158.

Hill, C. W. L \& Jones, T. M. (1992) Stakeholder-Agency Theory, Journal of Management Studies, 29, pp.131-154.

Hillman, A. J., Keim, G. D. \& Luce, R. A. (2001) Board Composition and Stakeholder Performance: Do Stakeholder Directors Make a Difference?, Business and Society, 40, pp.295-314.

Hobijn, B. \& Jovanovic, B. (2001) The Information-Technology Revolution and the Stock Market: Evidence, American Economic Review, 91, pp.1203-1220.

Holmström, B. (1999) The Firm as a Sub-Economy, Journal of Law, Economics and Organizations, 15, pp.74-102.

Holmström, B. \& Roberts, J. (1998) The Boundaries of the Firm Revisited, Journal of Economic Perspectives, 12, pp.73-94.

Ittner, C. D., Lambert, R. A. \& Larcker, D. F. (2003) The Structure and Performance Consequences of Equity Grants to Employees of New Economy Firms, Journal of Accounting and Economics, 34(1-3), pp.89-127.

Jacobides, M. G. (2005) Industry Change through Vertical Disintegration: How and Why Markets Emerged in Mortgage Banking, Academy of Management Journal, 48, pp.465498. 
Jensen, M. C. \& Meckling, W. H. (1976) Theory of the Firm: Managerial Behavior, Agency Costs and Ownership Structure, Journal of Financial Economics, 3, pp.305-360.

Keenan, J. \& Aggestam, M. (2001) Corporate Governance and Intellectual Capital: Some Conceptualizations, Empirical Research-Based and Theory-Building Papers, 9, pp.259275.

Klein, B. (1991) Vertical Integration as Organizational Ownership: the Fisher Body - General Motors Relationship Revisited, in: O. E. Williamson \& S. Winter (Ed.), The Nature of the Firm: Origins, Evolution, and Development (New York, Oxford University Press).

Klein, B., Crawford, R. G. \& Alchian, A. A. (1978) Vertical Integration, Appropriable Rents, and the Competitive Contracting Process, Journal of Law and Economics, 21, pp.297-326. Kochan, T. A. \& Rubinstein, S. A. (2000) Toward a Stakeholder Theory of the Firm: The Saturn Partnership, Organization Science, 11, pp.367-386.

Kreps, D. M. (1997) Intrinsic Motivation and Extrinsic Incentives, American Economic Review, 87, pp.359-364.

Laffont, J-J \& Martimort, D. (1997) The Firm as a Multicontract Organization, Journal of Economics and Management Strategy, 6, pp.201-234.

Langlois, R. (2003) The Vanishing Hand: The Changing Dynamics of Industrial Capitalism, Industrial and Corporate Change, 12, pp.351-385.

Leiblein, M. J. \& Miller, D. J. (2003) An Empirical Examination of Transaction-and Firmlevel Influences on the Vertical Boundaries of the Firm, Strategic Management Journal, 24, pp.839-859.

Lund Vinding, A. (2006) Absorptive Capacity and Innovative Performance: A Human Capital Approach, Economics of Innovation and New Technology, 15(4-5), pp.507-517.

Luoma, P. \& Goodstein, J. (1999) Stakeholders and Corporate Boards: Institutional Influences on Board Composition and Structure, Academy of Management Journal, 42, pp.553-563 
Mahoney, J. M., Asher, C. C. \& Mahoney, J. T. (2005) Towards a Property Rights Foundation for a Stakeholder Theory of the Firm, Journal of Management and Governance, 9, pp.5-32.

Milgrom, P. R. \& Roberts, D. J. (1992) Economics, Organization and Management (Englewood Cliffs: Prentice-Hall).

Milgrom, P. R. \& Roberts, D. J. (1995) 'Complementarities and Fit: Strategy, Structure, and Organizational Change in Manufacturing', Journal of Accounting and Economics, 19, pp. 179-208.

Morroni, M. (2006) Knowledge, Scale and Transactions in the Theory of the Firm, (Cambridge, Cambridge University Press).

Myers, S. C. (2000) Outside Equity, Journal of Finance, 55, pp.1005-1037.

OECD (2005) Growth in Services: Fostering Employment, Productivity and Innovation, Meeting of the OECD Council at Ministerial Levelt.

Osterloh, M. \& Frey, B. S. (2000) Motivation, Knowledge Transfer, and Organizational Forms, Organization Science, 11, pp.538-550.

Oyer, P. \& Schaefer, S. (2005) Why Do Some Firms Give Stock Options to All Employees?: An Empirical Examination of Alternative Theories, Journal of Financial Economics, 76, pp.99-133

Penrose, E. T. (1959) The Theory of the Growth of the Firm, $1^{\text {st }}$ edn (Oxford, Oxford University Press).

Porter-Liebeskind, J. (2000) Ownership, Incentives and Control in New Biotechnology Firms, in: M. M. Blair \& T. A. Kochan (Ed) The New Relationship: Human Capital in the American Corporation, pp.299-333 (Washington, Brookings Institution Press).

Prahalad, C. K. \& Hamel, G. (1990) The Core Competence of the Corporation, Harvard Business Review, 68, pp.79-91. 
Rajan, R. G. \& Zingales, L. G. (1998) Power in a Theory of the Firm, Quarterly Journal of Economics, 113, pp.387-432.

Rajan, R. G. \& Zingales, L. G. (2000) The Governance of the New Enterprise, in: X. Vives (Ed) Corporate governance: Theoretical and Empirical Perspectives, Chap 6, pp.201-227 (Cambridge, Cambridge University Press).

Rajan, R. G. \& Zingales, L. G. (2001) The Firm as a Dedicated Hierarchy: A Theory of the Origins and Growth of Firms, Quarterly Journal of Economics, 116, pp.805-851.

Roberts, J. \& Van den Steen, E. (2000) Stakeholder Interests, Human Capital Investment and Corporate Governance, Stanford GSB Working Paper $n^{\circ} 1631$.

Shleifer, A. \& Vishny, R. W. (1997) A Survey of Corporate Governance, Journal of Finance, 52, pp.737-783.

Simon, H. A. (1951) A Formal Theory of the Employment Relationship, Econometrica, 19, pp.293-305.

Teece, D. J. (2000), Managing Intellectual Capital: Organizational, Strategic, and Policy Dimensions (Oxford, Oxford University Press).

Teece, D. J., Pisano, G. \& Shuen, A. (1997) Dynamic Capabilities and Strategic Management, Strategic Management Journal, 18, pp.509-533.

Williamson, O. E. (1975) Markets and Hierarchy (New York, Free Press).

Williamson, O. E. (1985) The Economic Institutions of Capitalism: Firms, Markets, Relational Contracting (New York, Free Press).

Williamson, O. E. (1991) Comparative Economic Organization: The Analysis of Discrete Structural Alternatives, Administrative Science Quarterly, 36, pp.269-296.

Zingales, L. G. (1998), Corporate Governance, in: P. Newman, (Ed) The New Palgrave Dictionary of Economics and the Law, pp.497-502, (London, Macmillan).

Zingales, L. G. (2000) In Search of New Foundations, Journal of Finance, 55, pp.1623-1653. 


\section{Notes}

${ }^{1}$ The solutions often involve strengthening shareholders' control rights and ability to negotiate contractual restraints on manager opportunism.

${ }^{2}$ Competencies, know-how and expertise, i.e. human capital, associated to a work organisation based on technologies and team production, are at the core of the productive activity of business services and computer engineering firms.

${ }^{3}$ According to Williamson, a governance structure is a contractual mechanism in charge of transactions (for more details, see Williamson, 1991).

${ }^{4}$ Williamson reduces the firm to vertical integration which according to him is the 'paradigmatic problem' (Williamson, 1985, p. 150).

${ }^{5}$ We study this question in depth in the next section of the paper.

${ }^{6}$ Information and communication technologies are at the core of the recent technological revolution (Greenwood \& Jovanovic, 1999; Hobijn \& Jovanovic, 2001; Brynjolfsson et al., 2002).

${ }^{7}$ For a complete survey of stakeholder theory, see Donaldson \& Preston (1995).

${ }^{8}$ Stakeholders are groups of individuals who have legal rights on and duties in the firm. Stakeholders include shareholders, managers, creditors, employees, customers, suppliers, etc. and each of these families of economic agents owns critical resources and expects in turn that their interests will be satisfied (Freeman, 1984).

${ }^{9}$ Yet, some authors try to overcome this theoretical failure by developing a stakeholder vision of the firm based on ICT raising the question of the nature and the boundaries of the firm (Mahoney et al., 2005).

${ }^{10}$ A critical resource can originate in the talent or particular skill of one of the firm's agents (the entrepreneur, a manager or another key employee). The critical resource can be a specific human capital and not a physical or an alienable capital. 
${ }^{11}$ We use the terms partners, stakeholders and employees interchangeably, to indicate corporate members whose characteristics are possession of human capital critical to the productive activity of the firm.

${ }^{12}$ Regulation of access includes not only access rights to the critical resource, but also the cooperation of the person that is specialised to. Moreover, regulation of access is not only a momentary action, but a 'process that cannot be continuously verified by courts' (Rajan $\&$ Zingales, 1998, p.403).

${ }^{13}$ This hold-up manifestation is significant because $71 \%$ of the firms recorded in the Inc 500 list were founded by talented employees who imitated or changed a growth opportunity built by their former employing firm (Bhide, 2000).

${ }^{14}$ The list of governance mechanisms examined is not exhaustive. The paper mentions the more relevant ones.

${ }^{15}$ Extrinsic motivation is achieved by actions that result in the attainment of externally tangible and intangible rewards, including pay, promotion, material possessions, prestige and the positive evaluations of others. Intrinsic motivation, on the other hand, is based on engagement in an activity for its own sake rather than to obtain material or social compensation. Moreover, motivations can be described along a control-to-autonomy continuum, from extrinsic motivations towards intrinsic ones (Gagné \& Deci, 2005). ${ }^{16}$ In some cases, these resources are employees occupying low positions in the hierarchy. 